\title{
MODEL OF FORMATION OF PRE-SERVICE TEACHERS' READINESS FOR TEACHING CHEMISTRY IN ENGLISH
}

\author{
Irina Babich, Master's Degree in Pedagogical Sciences, PhD student of the Higher School of Natural \\ Sciences of Pavlodar state pedagogical university, Pavlodar, Republic of Kazakhstan, \\ ORCID ID: https://orcid.org/0000-0001-5861-6260 \\ Zarina Shakirova, English teacher, Nazarbayev Intellectual School in Pavlodar, Pavlodar, Republic \\ of Kazakhstan \\ DOI: https://doi.org/10.31435/rsglobal_conf/25122020/7309
}

\begin{abstract}
This study aims to develop a framework and model of pre-service teachers' readiness for teaching Chemistry in English. The three-component structure of readiness is defined by the authors as a complex personal education, which includes knowledge of the subject-methodological and linguistic content in their integration, the ability to plan and implement what is planned in practice, evaluate and make changes, positive motivation (attitude) to the process being implemented. The model of the formation of pre-service teachers' readiness for teaching Chemistry in English is described in detail. The model is constructed on the basis of a system, competency building, socio-constructivist and personalactivity approaches. Its theoretical and methodological basis is the theory of the relationship of thinking and speech by L.S. Vygotsky, BICS / CALP J. Cummins, theory of Scaffolding, theory of Speech Activity and the taxonomy of learning objectives in Bloom's cognitive domain. The article formulates special competencies necessary for pre-service teachers, the conditions for their readiness, and methodological principles of teaching. The methods of basic teaching of the elective course "Learning and Teaching Chemistry in English" are described in detail, based on the integration of two innovative approaches Content and Language Integrated Learning (CLIL) and Inquiry Based Learning (IBL).
\end{abstract}

Keywords: readiness, model, pre-service teachers, CLIL, IBL, Chemistry.

Introduction. In the strategic development plan of the Republic of Kazakhstan until 2025 (State Program Of Education Development in the Republic of Kazakhstan for2020-2025, 2019) one of the priority tasks in the field of education as the basis for economic growth is the initiative to switch to teaching subjects in high school in English. This is due to the entry of Kazakhstan into the world economic space and the need to ensure the competitiveness of the country's economy. The use of the English by pupils, students, specialists provide them with access to world information bases, will allow them to exchange with received information in the professional sphere, and will contribute to the development of science and modern technologies. In this regard, the issue of training future specialists - teachers of natural science disciplines, teaching in a foreign language is exiting.

In the pedagogical universities of the country, there are positive changes in the direction of integrating English into the disciplines of the non-linguistic cycle. Integration is carried out through programs such as "Foreign language for special purposes", "Professional English", the study of natural science subjects in English. However, our research (Babich et al., 2020) showed that pre-service teachers still have an insufficiently high level of proficiency in academic English, are not ready to organize communication in the classroom, give formative feedback to students, and timely respond to their cognitive needs. They are having trouble in lesson planning and choose teaching methods and believe that teaching in a foreign language requires special methodological training. The solution to this problem is provided for in the strategic development plan of the Republic of Kazakhstan until 2025 , which proposes to update the curricula and educational programs for the training of teaching staff in order to introduce new methods of teaching English (State Program Of Education Development in the Republic of Kazakhstan for2020-2025, 2019).

In this regard, the question of forming the readiness of pre-service teachers to teach subjects of the natural science cycle (including Chemistry) in English becomes relevant.

In the Big Explanatory Dictionary, readiness is defined as readiness for something, the ability to do something. (Big Explanatory Dictionary of the Russian Language: 120 thousand words, 2019)

The problem of the readiness of specialists for various types of activity is paid much attention in psychology and in pedagogy. We will consider the problem of forming the readiness of pre-service teachers for teaching Chemistry in English as one of the aspects of professional readiness.

In psychological research, readiness is often defined as the manifestation of a certain level of ability (Rubinshtein, 2013) as a psychological attitude (Uznadze, 1961). 
A large number of researchers (Katz \& Stotland, 1959; Maiers, 2011; Petrovskii et al., 1996; Sardzhveladze, 1989; Uznadze, 1978) describe the structure of a psychological attitude, consisting of three components: cognitive (knowledge or belief of a person about the object of the installation), emotionalevaluative or affective (emotional assessment of an object, revealing a feeling of sympathy or antipathy towards it) and behavioral (willingness to act in a certain way in relation to the object of installation).

In pedagogical research, readiness and professional readiness are considered as multicomponent systems (V.A. Slastenin) and as a complex of properties and personality traits (V.A. Krutetsky).

V.A. Krutetsky (Krutetsky, 1976) believes that readiness is a set of personality traits that determine its compliance, suitability for activity: an active, positive attitude towards it; a favorable mental state during its implementation; a set of knowledge, skills and abilities in a particular area; specific sensory and mental characteristics that meet the requirements of the activity. So, according to V. Lifrieri opinion (Lifrieri, 2005) and A. Siddiq K. (Ahmad Siddiq et al., 2019) a positive attitude is essential for achieving results in the field of language.

M.I. Dyachenko, L.A. Kandybovich (Dyachenko \& Kandybovich, 1976) believe that readiness arises on the basis of needs, motives, goals of activity and contributes to the further development of plans, attitudes of future actions. The components of professional readiness are motives and attitudes, interests, tendency, convictions, intentions that determine the professional readiness of an individual for a specific professional activity.

R. Gardner (Gardner, 2007) believes that positive attitudes coupled with motivation affect the speed and success of learning a second language. Investigating the motivational factors of learning English among Spanish students, R. Gardner came to the conclusion that more motivated students have better results than less motivated ones. Students, who see instrumental value in learning English language, do better.

On the one hand, the formation of a positive attitude towards the study of special subjects in English is a strong motivational incentive for pre-service chemistry teachers to further implement it (My article ENU). On the other hand, studies by Keita Kikuchi have shown that classmates or teachers can motivate positive attitudes towards learning academic English (Kikuchi, 2019).

Research by M.I. Dyachenko, L.A. Kandybovich continues V.A. Slastenin. (Slastenin, 2013) It defines readiness for professional activity as a complex synthesis of psychological (focus on activity, positive motivation), scientific and theoretical (knowledge), practical (professional skills and abilities), psychophysical components (professionally significant personal qualities).

V.A. Slastenin, S.L. Rubinstein, S.L. Shcherbakov, (Rubinstein, 2013; Slastenin, 2013; Shcherbakov, 1971) believe that an important component of a teacher's professional readiness is his readiness to interact and communicate with students. From the point of view of the formation of readiness for teaching in English and in accordance with the theory "BICS / CALP" J. (Cummins, 1984), pre-service chemistry teachers should have good command of basic communication skills of everyday communication "BICS" (basic interpersonal communicative skills) and cognitive / academic language skills "CALP" (cognitive / academic language proficiency). BICS describes the development of speaking and language skills required by prospective teachers in everyday communication and are a contextually embedded language. Baker (Baker, 2006) characterizes CALP as an academic language (often abstract) used in the classroom in a "limited context" when non-verbal cues are absent and higher-order thinking skills (analysis, synthesis, assessment) are required.

Thus, the analysis of psychological and pedagogical studies of the structure of readiness for professional activity shows that a large number of scientists determine three main components of readiness: motivational, cognitive (knowledge, high-order skills) and praxeological (professional skills and abilities).

The cognitive and praxeological components of the readiness of pre-service teachers to teach chemistry in English are formed in the process of applying subject-language integrated learning (CLIL), recommended by the European Commission for use in higher education. CLIL allows you to study chemistry, teaching methods, and English at the same time. Learning with CLIL, teacher training graduates gain the content integration and language teaching experience they need to work in the classroom. The 4C model proposed by Coyle (Coyle, 1999) provides support of pre-service teachers in lesson planning and teaching. Coyle identifies four components of a successful lesson: content (subject content), communication (language of instruction, language for teaching, language through teaching), cognition (development of high-order thinking skills), and culture (intercultural interaction).

The motivational component of readiness can be formed during the application of InquiryBased Learning (IBL). This approach allows the content of the curriculum to be tailored to the interests and curiosity of students. It facilitates the communication of pre-service teachers in the 
process of collaborative problem solving and the development of metacognitive skills, a deep academic understanding of chemistry and its teaching methodology, which is associated with the development of academic English. The use of IBL lowers the "affective filter" of students (Krahnke \& Krashen, 1983) and makes learning emotionally attractive.

Thus, the integration of CLIL and IBL approaches will provide support for students in the formation of the three components of readiness for teaching Chemistry in English.

In our research, we set a goal to develop a structure and model of the formation of pre-service teachers' readiness for teaching Chemistry in English.

To create a holistic system which reflects the characteristics, characteristics and functional parameters of readiness, we used a modeling method.

Methods of the research. The construction of the model was carried out on the basis of a systemic, competence-based, socio-constructivist, personal-active approaches. The theoretical and methodological basis of the model is the theory of the relationship of thinking and speech by L.S. Vygotsky, J. Cummins BICS / CALP theory, scaffolding theory, taxonomy of learning objectives in Bloom's cognitive domain, theory of speech activity.

From the point of view of a systems approach, we define readiness for teaching Chemistry in English as an integrative quality of a person, which ensures quick adaptation to activity, its improvement and includes interrelated and mutually influencing components: motivational, cognitive, praxeological.

From the point of view of the competence-based approach, we have identified the basic competencies required for a teacher to teach chemistry in English. The definition was carried out using the ranking not grouped ordered series of the most significant competencies indicated by practicing teachers, which are described in the European Framework for the Professional Development of Teachers CLIL (Marsh et al., 2012) and within the competence of Bertaux (Bertaux et al., 2010) The study involved 24 chemistry teachers with a total work experience of 14 to 35 years.

The integration of CLIL and IBL ensured the implementation of personality-activity, socioconstructivist approaches in the process of fulfilling the request cycle by students.

Based on the systemic, competence-based, personality-activity, socio-constructivist approaches, we have identified the main characteristics of the constructed model:

- relevance - the relevance of the model, its relevance and significance for the formation of pre-service teachers' readiness for teaching Chemistry in English;

- dynamism - the model provides for the formation of readiness for teaching in English in the dynamics of the development of communicative and cognitive skills and abilities of students, changes in the degree of support from the teacher;

- integrity - the model contains all components (target, meaningful, procedural, reflexiveproductive) that ensure the achievement of expected results: formation of pre-service teachers' readiness for teaching Chemistry in English;

-informativeness - the model contains a sufficient amount of information necessary to determine the direction and methods and assess the level of readiness of pre-service teachers' readiness for teaching Chemistry in English.

Thus, the model for the formation of pre-service teachers' readiness for teaching chemistry in English represents a certain organization of the educational activities of students, aimed at the formation of their special competencies.

Results of the research. The analysis of the content of the competencies selected by practicing teachers allowed us to divide them into four main groups: basic competencies of a Chemistry teacher in English (knowledge of various sections of chemistry, general, academic, "chemical" English and classroom management language, methodology - CALP, approaches to assessing student achievement in English), competency of the lesson planning, (planning learning outcomes, choosing content and resources, adapting authentic materials, teaching techniques, developing assignments and assessment strategies), implementation of the plan into practice (competencies in supporting the development of general, academic, "chemical" English, productive cognitive skills, high-order thinking, cultural consciousness and interculturality, multimodality, culture of educational assessment, ensuring a safe and supportive environment), assessment of teaching in English (the competence of assessing and selfassessing progress in teaching chemistry in English and making decisions on development directions). All these competencies are related to the formation of pre-service teachers' readiness to teach in English and do not take into account the general professional competencies that are formed in the process of studying at the university: managing their professional development and class management, establishing 
constructive relationships with students, working with other participants in the educational process to improve student learning, use interactive methods to support student-centered learning, and others.

The structure of readiness for teaching Chemistry in English is shown in Figure 1.

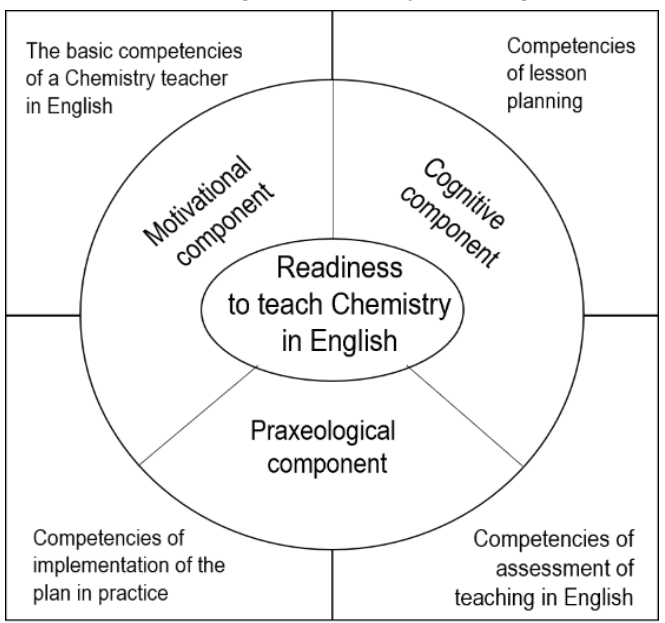

Fig. 1. The structure of readiness for teaching Chemistry in English

Thus, we define the readiness for teaching Chemistry in English as a complex personal education, which includes knowledge of subject-methodological and linguistic content in their integration, the ability to plan and implement what is planned in practice, evaluate and make changes, positive motivation (attitude) to the implemented process.

Analysis of International and Kazakh experience, our own teaching practice allowed us to formulate and experimentally confirm the effectiveness of the following conditions for the formation of pre-service teachers' readiness for teaching Chemistry in English:

- availability of qualified CLIL teachers with knowledge of language subject, pedagogical competencies;

-he presence of an effective, emotionally literate environment that motivates pre-service teachers for teaching Chemistry in English;

-implementation of training through the integrated course program "Learning and teaching Chemistry in English", which includes subject, linguistic and methodological components of the theory and practice of teaching chemistry;

- using the integration of CLIL and IBL (inquiry-based learning) techniques to involve preservice chemistry teachers in self-organized interactive learning in the subject-pedagogical field;

- providing systemic reflexive practice of pre-service teachers in planning and conducting chemistry lessons in English.

We have identified the main provisions of the process of formation of readiness for teaching Chemistry in English that are relevant for our research: general didactic, general methodological principles, didactic principles of subject-language integrated learning and learning based on requests (Table 1).

Table 1. Principles of formation of readiness for teaching Chemistry in English

\begin{tabular}{|c|c|c|}
\hline № & Groups of principles & Principles \\
\hline 1 & $\begin{array}{l}\text { General didactic (taking into } \\
\text { account general patterns) }\end{array}$ & $\begin{array}{l}\text { individualization and differentiation of training; activity; } \\
\text { availability; optimality; developing high-order thinking skills; unity } \\
\text { of thought and speech activity; psychological comfort }\end{array}$ \\
\hline 2 & $\begin{array}{l}\text { General methodological (taking } \\
\text { into account the specifics of } \\
\text { teaching disciplines) }\end{array}$ & communicative orientation; authenticity \\
\hline 3 & $\begin{array}{l}\text { Principles of subject-language } \\
\text { integrated learning }\end{array}$ & $\begin{array}{l}\text { principle "4 C"; integration of chemical, methodological and } \\
\text { linguistic content; duality-reliance on the first and foreign language; } \\
\text { multiculturalism; multimodality; scaffolding (optimal support in the } \\
\text { learning process) }\end{array}$ \\
\hline 4 & $\begin{array}{l}\text { Principles of Query-Based } \\
\text { Learning }\end{array}$ & $\begin{array}{l}\text { learners are in the center of the entire process; peer-to-peer } \\
\text { collaboration; students as researchers; teachers as research } \\
\text { assistants; reflecting on learning }\end{array}$ \\
\hline
\end{tabular}

The model for shaping of pre-service teachers' readiness for teaching Chemistry in English includes target, meaningful, procedural, diagnostic, and effective blocks (Figure 2). 


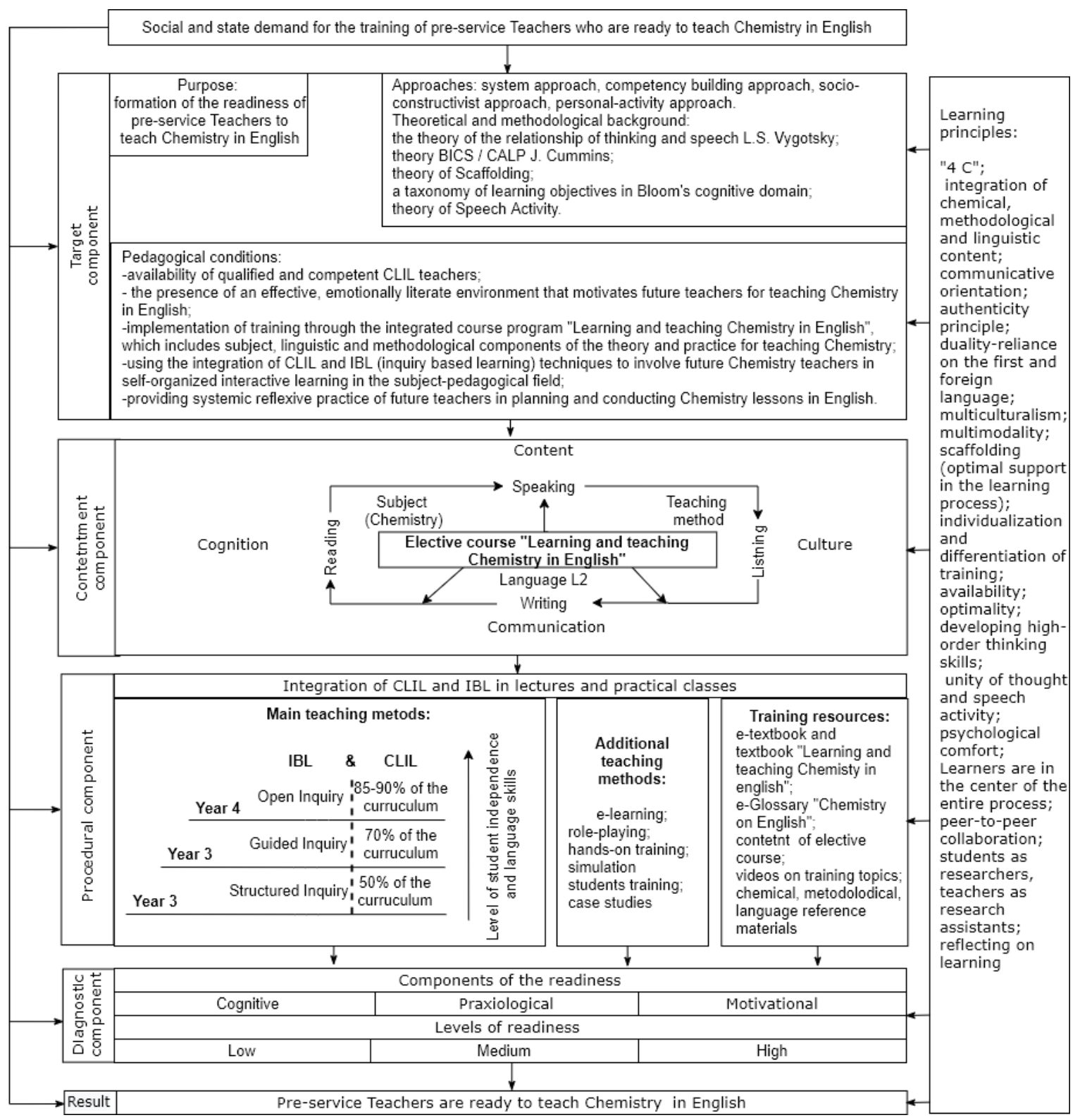

Fig. 2. The model for shaping of pre-service teachers' readiness for teaching Chemistry in English

The purpose of the model is to form the readiness of pre-service teachers for teaching Chemistry in English. The content block is presented by the knowledge gained by pre-service teachers in the course of studying the elective course "Learning and Teaching Chemistry in English" in the field of subjectmethodological and language content, the development of communication, cognitive skills and intercultural interaction skills in the process of reading, speaking, listening, writing. The procedural block includes a demonstration of the application of the basic CLIL and IBL methods in their integration and in the dynamics of decreasing support from the teacher, additional methods used to form readiness, resources and forms of training for pre-service teachers. We study Chemistry and methods of teaching it in English with a gradual reduction in guidance and support from teachers of language and subject knowledge and an increase in the percentage of use of English by pre-service teachers in the classroom from $50 \%$ in the 2 nd year to $70 \%$ in the 3rd year and up to $85-90 \%$ on the 4th year. Much attention is paid to the development of the ability to observe the lesson of fellow students and to formulate feedback. The teacher's role gradually changes from being a leader and practical assistant to being a supportive mentor. In the 4th year, the minimum teacher support is aimed at increasing students' confidence and independence in designing and delivering lessons. Students, applying the knowledge and skills gained on the 2nd and 3rd year, individually plan lessons, independently develop multi-level assignments, using CLIL techniques and methods aimed at organizing students' independent work. The formation of the necessary competencies is carried out in the course of lectures and practical exercises. To achieve the 
goal of the model, electronic resources were developed: a glossary of chemical and pedagogical terms, classroom management words, an electronic textbook "Learning and Teaching Chemistry in English", training videos, reference materials in the subject, methodological, and language areas were selected. The diagnostic block includes the formulated components of readiness and the levels of their formation. The result of the implementation of the model should be the formation of a competence specialist who is ready for teaching Chemistry in English.

Conclusions. Thus, the implementation of the proposed model can contribute to the formation of future teachers' readiness for teaching Chemistry in English, since it is aimed at the formation of all three of its components: motivational, cognitive and praxeological.

Evidence of the effectiveness of the model of formation of pre-service teachers' readiness for teaching Chemistry in English is currently carried out during the industrial practice of students studying for three semesters using the Model and content of the elective course "Learning and Teaching Chemistry in English".

\section{REFERENCES}

1. Ahmad Siddiq, K., Miri, M. A., \& Sarwarzada, T. (2019). Afghan Students' Attitudes and Motivations Toward ESP and EGP Courses. Language In India, 19(6), 354. http://languageinindia.com/june2019/v19i6june2019part3.pdf\#page =50

2. Babich, I. M., Baratova, A. A., \& Shomanova, Z.K. (2020). Exploring preservice chemistry teachers' attitudes towards learning a subject in english in Kazakhstan. BULLETIN of Pedagogical Sciences, №2(66), 265-271.

3. Baker, C. (2006). Foundations of Bilingual Education and Bilingualism Fourth Edition. BILINGUAL EDUCATION AND BILINGUALISM, 54.

4. Bertaux, P., Coonan, C. M., Frigols-martín, M. J., \& Mehisto, P. (2010). the Clil Teacher's Competences Grid. 1-9.

5. Big Explanatory Dictionary of the Russian Language: 120 thousand words. (2019) Edited by D. N. Ushakov Publishing house: Standard Year of publication: 2019.

6. Coyle, D. (1999). Theory and planning for effective classrooms: Supporting students in content and language integrated learning contexts. Learning through a Foreign Language, 46-62.

7. Cummins, J. (1984). Bilingualism and special education: issues in assessment and pedagogy. Clevedon: Multilingual Matters Ltd.

8. Gardner, R. C. (2007). Motivation and Second Language Acquisition. PORTA LINGUARUM, 8, 9-20. https://digibug.ugr.es/bitstream/handle/10481/31616/Gardner.pdf?sequence=1\&isAllowed=y

9. Katz, D., \& Stotland, E. (1959). A preliminary statement to a theory of attitude structure and change. Psychology: A Study of a Science, 3(423-475).

10. Kikuchi, K. (2019). Motivation and demotivation over two years: A case study of English language learners in Japan. Studies in Second Language Learning and Teaching, 9(1), 157-175. https://doi.org/10.14746/ssllt.2019.9.1.7

11. Krahnke, K. J., \& Krashen, S. D. (1983). Principles and Practice in Second Language Acquisition. TESOL Quarterly, 17(2). https://doi.org/10.2307/3586656

12. Lifrieri, V. (2005). A sociological perspective on motivation to learn EFL: The case of Escuelas plurilingües in Argentina. 1-107. https://clck.ru/M6zQ6

13. Marsh, D., Mehisto, P., Wolff, D., \& Frígols-Martín, M. J. (2012). European Framework for CLIL Teacher Education. A framework for the professional development of CLIL teachers. In Encuentro (Vol. 21). http://clilcd.ecml.at/EuropeanFrameworkforCLILTeacherEducation/tabid/2254/language/en-GB/Default.aspx

14. State Program of Education Development in the Republic of Kazakhstan for2020-2025 (2019). Adilet. Information and legal system of normative legal acts of the Republic of Kazakhstan. http://adilet.zan.kz/rus/docs/P1900000988

15. D'yachenko, M. I., \& Kandybovich, L. A. (1976). Psychological problems of readiness for activity. BSU Publishing House.

16. Krutetskii, V. A. (1976). Psychology of teaching and upbringing of schoolchildren: a book for teachers and class teachers. Education.

17. Maiers, D. (2011). Social psychology: [trans. from English]. Publishing house "Peter"

18. Petrovskii, A. V., Brushlinskii, A. V., Zinchenko, V. P. et al (1996). Introduction to Psychology. Introduction to Psychology.

19. Rubinshtein, S. L. (2013). Fundamentals of General Psychology. Peter-Trade.

20. Sardzhveladze, N. I. (1989). Personality and its interaction with the social environment. Academy of Sciences of the Georgian SSR, Institute of Psychology. D. N. Uznadze.

21. Slastenin, V. A. (2013). Pedagogy. Textbook. Manual for Stud. Higher. Ped. Textbook. Establishments Publishing Center Academy.

22. Uznadze, D.N. (1961). Experimental Foundations of Attitude Psychology Acad. Sci. Cargo. SSR. Institute of Psychology. D. N. Uznadze.

23. Uznadze, D. N. (1978). General teaching about installation. Psychology Reader: A Textbook For Students Of Pedagogical Institutes: [Comp. VV Mironenko, Ed. AV Petrovsky] Education, 101-108.

24. Shcherbakov, A. I. (1971). Psychological structure of personality and patterns of its formation. Personality Psychology and Educational Psychology. LGPI them. AI Herzen, 3-31. 